\title{
PAYROLL MODEL FOR ACADEMIC STAFF: A REAL OPTION IN A PRIVATE CAMPUS
}

\author{
*Nunuh ${ }^{1}$, Arvina Wulandari ${ }^{2}$ \\ ${ }^{1}$ Trisakti Institute of Transportation and Logistics, Jakarta, Indonesia \\ ${ }^{2}$ Muhammadiyah Business Institute of Bekasi \\ *Coresponding author. \\ E-mail addresses: nunuh0163@gmail.com
}

\begin{abstract}
ARTICLE INFO ABSTRACT

Article history:

Received:

21 August 2021

Accepted:

15 October 2021

Available online:

26 November 2021

The purpose of this study is to describe and provide input to the outside world that real thoughts are needed for educational staff in an institution that works. So far, educational staff in a campus institution differ in their salary, as an illustration that there is a campus that provides salaries to education staff in a large range with the educational standards of undergraduate graduates according to the needs of the positions on campus. The method used is to obtain case data in reality received by education personnel who work in campus institutions. The results of the study require good follow-up thinking using quantitative methods by looking for other variables that influence each other and qualitative methods that provide good results from informants, finished data, or comparing.
\end{abstract}

Keyword: Education Personnel, Payroll Model, Institution

\section{INTRODUCTION}

In running an organization or institution, human resources are needed that will assist the organization in developing in accordance with the goals of the organization and the owner of the organization or institution. In a private institution the fulfillment of human resources in occupying very vital and helpful positions, without human resources that can help the institution will not run properly and effectively. Employers see the added value of employees before providing work according to the vacancy (Perufo, J. V., Ozório, L. D. M., Bastian-Pinto, C. D. L., \& Barros, S. D. J. M. D., 2018). Academic staff recruited by campuses are sought in accordance with the existing positions according to their needs, on campuses in Indonesia, especially private campuses, vary in organizational structure models, in general they are almost the same from one campus to another.

The organizational structure in private campuses in Indonesia is broadly for high schools as follows for top positions there is a chairman, after that there is a vice chairman of the academic field where in the order under the vice chairman of this academic field there is a head of study program (depending on how many study programs there are) Under the head of the study program there is a study program secretary (as needed) after that there is an operational staff in the academic field who helps the head of the study program, a vital role in a study program is in the academic operational staff, which runs, accommodates lecture 
schedules for lecturers and students (assisted education technology staff), overseeing the course of lectures either in class or online (e-learning).

Academic staff have a role if students fail in terms of performance (KaireKollom, Kairit Tammets, MarenScheffel, Yi-ShanTsai, IoanaJivet, Pedro J. Tobias Ley, 2020). After the structure for the academic field, there is a vice chairman for human resources, finance and student affairs (there are several large private campuses with a vice chairman to vice chairman for student affairs), vice chairman for these two other names for medium-sized private campuses or capital structures. which is not great. The regulations governing the working organization of the coordination of private universities are in accordance with the Regulation of the Minister of Education and Culture of the Republic of Indonesia Number 1 of 2013.

In the second vice chair, there are various positions such as the human resources department (human resources department for lecturers and human resources for institutions or campuses that run campus management), then there is a general section and educational facilities, student affairs (if the campus stated above does not great for a private campus). In addition, this structure also takes care of the payroll of all human resources to lecturers. The salaries of lecturers, leaders and staff (called academic staff) are carried out in various ways, some starting at the beginning of the month, such as some private universities that provide salaries every date at the beginning of the month, besides that there are also private campuses that provide salaries on each date at the end of the month. The salary models are also different from state universities which are financed or subsidized by the state and the status of academic staff at state universities as well as civil servants.

The difference between academic staff at public and private campuses is their status, also the salary is also different, for academic staff or more likely to be called civil servants, salaries at state campuses have been regulated by the state based on the employee's class and educational status, as an illustration for graduates. diploma three then the employee class is $2 \mathrm{~B}$, for undergraduate employees (bachelor) the class is $3 \mathrm{~A}$, while for master's graduates the employee group is $3 \mathrm{~B}$. On state campuses, the total salary value is the same from one campus to another as stated above. For civil servants for academic staff, for a class increase there is a performance assessment, of course, it will increase the salary of the employee. As an illustration of overseas campus assessments to assess performance using technology or what is called e-assessment (Nasser Binsaif, 2021). Educational staff (academic staff) on private campuses under each head of the study program in assisting work operations on campus, these educational staff work according to the positions and job descriptions that have been agreed upon at the time of the initial interview.

There are educational staff in a private campus with educational levels ranging from high school to master's level, but with the regulation from the Directorate of Higher Education that current education staff must have the lowest education level with a bachelor's degree. Almost all private universities have adjusted to the stipulated provisions, it's just that there are educational staff who occupy positions that are not in accordance with the competencies they occupy, such as for the secretariat and general sections, sometimes indirect graduates are graduates of administration, communication and technology departments are occupied with competencies that are not computer graduates or field. This creates a dilemma for some private campuses. Experience is important (Burns, M, 2000).

The salary model on private campuses for academic staff with various models cannot be used as a basis or benchmark, private campuses in Indonesia, especially Jakarta with a large capital structure from the owner or the Foundation as the owner of the capital, if the private campus is large the mode is usually the payroll model for academics the staff is also large, but unlike private universities whose capital structure is not large, the salary for academic staff is not in accordance with the salary standards set by regional or provincial minimum wage standards. The difference in the salary of academic staff creates a gap that will be presented and maybe later it can be continued in other research. Academic staff who work at private campuses just accept the salary given with the workload that is fulfilled according to the job description, private campuses as private institutions in particular do not have the power and follow directions from the Foundation as the owner of a private campus. After being described from the above description of three things, namely the institution (private campus), academic staff and the salary model, this phenomenon is used as a phenomenon that will make this research appear, the gaps in this research have also been conveyed and can be discussed. 


\section{LITERATURE REVIEW}

According to the previous description, that the role of academic staff according to the three domains of teaching, research, and service, with the main emphasis placed on aspects of teaching and research and a secondary emphasis on service or administration. (Don Houston, Luanna H. Meyer \& Shelley Paewa, 2006). Academic staff in a higher education institution are Human Resources who have a major role to play an important role in higher education institutions. (Boran Toker, 2009). In the general provisions of the National Education System Law, educators are educational personnel who are qualified as teachers, lecturers, counselors, civil servants, widiaswara, tutors, instructors, facilitators and other names that are in accordance with their specificity and participate in the administration of education. (Anwar Arifin, 2003).

Educational staff are members of the community who devote themselves and are appointed to support addministration. This means that education personnel have a role as administrative staff or educational supervision that supports the implementation of education in tertiary institutions, as well as a role as technical service personnel which aims to provide types of services related to the learning process in higher education. Education staff can also be people who can determine the level of success and fluency in the learning process in universities. (Handoko Hani, 2008). Management of educators and education is an activity that must be carried out starting from the educators and educational staff entering the educational organization until finally stopping through the process of human resource planning, recruitment, selection, placement, awarding, awarding, education and training, development and dismissal. The management of education personnel (teachers and employees) absolutely must be applied by the principal in order to be able to utilize the educational staff effectively and efficiently to achieve optimal results. (Pure Pure, 2017).

The salary level is higher than the budget, making paying teachers a higher salary scale, but no additional (Ellen Greaves Luke Sibieta, 2019). Dissatisfaction makes the salary factor inadequate for faculty in determining salaries for teaching staff. (Matthew M. Murawski, RPh, PhDa, ${ }^{*}$, Brenden J. King, PharmDb, 2011). Salary according to Anonymous, namely salary is one of the important elements that can affect employee performance, because salary is a tool to meet various employee needs, so that with the salary given, employees will be motivated to work harder. (Hariandja, 2002). Salary or wage is an acceptance as a reward from the employer to the recipient of work for a job or service that has been and will be performed to function as a guarantee for the continuity of a decent life for humanity and production, salary or wages are stated/valued in the form of money determined according to a approvals, laws and regulations and paid on the basis of an employment agreement between the employer and the employee. (Ariani, 2010).

\section{CONCLUSION AND RECOMMENDATION}

From the results of the above description of the three variables displayed in this article, namely education personnel, payroll models, and institutions (private campuses), then provide input on three variables. So far, educational staff in a campus institution differ in their salary, as an illustration that there is a campus that provides salaries to education staff in a large range with the educational standards of undergraduate graduates according to the needs of the positions ovariables. The method used is to obtain case data in reality received by education personnel who work in campus institutions. The results of the study require good follow-up thinking using quantitative methods by looking for other variables that influence each other and qualitative methods that provide good results from informants, finished data, or comparing.

\section{REFERENCES}

Ade Supandi, "Development of the Navy's Strength in Support of Indonesia's Vision as a World Maritime Axis". Defense Journal, August 2015, Vol.5 Number 2

Andrej Bujak. "The Development of the Concept of Supply Chain Management As An Example of the Evolution of Logistics". The Wroclaw School of Banking Research Journal, Volume 15, No.1 2015

Arawati Agus, "Supply Chain Management and Competitive Differentiation". International Business Managements Journals, Vol.9. No.5, 2015

Bas Rietjens, Ton van Kampen and Tim Grant, Logistics Planning and Control: Lesson Learned in Afghanistan, in Joseph Soeters, Paul C. Van Fenema and Robert Beeres (et.all). Managing Military Organizations: Theory and Practice. London: 2010, Routledge 
Beni Ahmad Saebani and Yana Sutisna. Research methods. Bandung: 2018, Librarian Faithful Publisher

Butje Tampi. "Natuan Islands Conflict between Indonesia and China (A Juridical Study)". Journal of Law Unsrat, Vol.23, No.10, April-December 2017

Cholid Nurboko and Abu Achmadi. Research methodology. Jakarta: 2012, Earth Literacy Publisher

Dharma Agung S.I. and Hollanda Arief K, "Organizing Naval Bases to Strengthen Indonesian Maritime Sovereignty". Journal of Diplomacy and Security Studies, Vol.9, Number 1 (2017)

Dicky R. Munaf and Susanto. Marine Security and Safety Control Command. Jakarta: 2015, Gramedia Main Library

Elizabeth Chang, Daniel D. Prior, and Florian Gottwalt, "Toward an Integrated System for Army Logistics Management", Australian Army Journal, Spring, Vol. XII, No. 2, 2016

I. Wibowo and Syamsul Hadi (et.all). Embrace China. Jakarta: 2009, PT Gramedia Pustaka Utama

Iman Ghozali, Structural Equation Modeling: Alternative Method with Partial Least Squares. Semarang:2014, Undip Publishing Agency

Jonathan Sarwono. Research Strategy. Yogyakarta: 2013, Publisher Andi

Lijan Poltak Sinambela. Human Resource Management. Jakarta: 2019, Earth Literacy Publisher

Manual for the Standardization of Navy Base Administration (PUM-7.03) 2013

Marsetio. SeaPower Indonesia. Jakarta: 2014, Defense University

NATO Headquarters. NATO Logistics Handbook. Brussels: 2012, NATO

Naval Headquarters. Hydro Oceanography White Paper. Jakarta: 2018, Naval Hydro Oceanography Center

Okol Sri Suharyo and Joko Purnomo, "Application of the Analytic Method Process (ANP) in Determining the Priority of Lanal Development (Navy Base) To Become Lantamal (Navy Main Base)". Journal of Systems and Operations Analyst, Vol.3 (2015)

P.J. Vlok, "Supply Chain Management: A Framework of Understanding". South African Journal of Industrial Engineering, November 2014, Volume 25, Issue 3

Philip Kotler. Marketing Management: Millennium Edition. Upper Saddle River, New Jersey: 2000, Prentice-Hall Inc

Presidential Decree No. 33 of 1982 concerning Coordination of Planning and Development of Teluk Ratai as the Main Base of the Western Territory of the Navy

Presidential Regulation No. 66 of 2019 concerning TNI Organization General Publication of the Navy (PUM-1.03)

Putu Yoga Arsana et al, "Model of Maritime Security Synergy by Naval Bases at Chokepoint Lombok Strait", Proceedings of the 4th National Marine and Fisheries Seminar 2018

Ricky Virona Martono. Logistics Management. Jakarta: 2019, PT Gramedia Pustaka Utama

Sanjay Sethi and Sunil Sharma, "Performance Measurement of Military Supply Chains", International Journal of Engineering and Management Research, Vol.8, Issue 2, April 2018

Sedarmiyanti, Human Resource Management: Bureaucratic Reform and Civil Service Management. Bandung: 2019, PT Refika Aditama

Sisriadi, "Development of Military Defense Posture to Support the Realization of the World Maritime Axis". Wira, Volume 59, No.43, March-April 2016

Sopiah and Etta Mamang Sangadji. Strategic Human Resource Management. Yogyakarta: 2018, Publisher Andi

Syaiful Anwar. Protect the Country. Jakarta: 2016, Indonesian Torch Library Foundation

Tedjo Edhy Purdijatno. Controlling Maritime Borders. Jakarta: 2010, Grasindo

Yusa Adi Hartanto, "Logistics Management in Improving Alutsista Readiness Indonesian Navy". Defense Journal, April 2016, Vol.6, Number 1 